\title{
Intestinal Sucrase Deficiency Presenting as Sucrose Intolerance in Adult Life
}

\author{
G. NEALE, $*$ M.B., M.R.C.P. ; M. CLARK, $†$ M.B., M.R.C.P. ; B. LEVIN, $\ddagger$ M.D., PH.D., F.C.PATH.
}

Brit. med. F., 1965, 2, 1223-1225

Diarrhoea due to failure of the small intestine to hydrolyse certain dietary disaccharides is now a well-recognized congenital disorder of infants and children. It was first suggested for lactose (Durand, 1958) and later for sucrose (Weijers et al., 1960) and for isomaltose in association with sucrose (Auricchio et al., 1962). It has been confirmed for lactose and for sucrose intolerance by quantitative estimation of enzyme activities in the intestinal mucosa (Auricchio et al., 1963b ; Dahlqvist et al., 1963 ; Burgess et al., 1964 ; Levin, 1964). In all cases presenting in childhood there is a history of diarrhoea when food yielding the relevant disaccharide is introduced into the diet. Symptoms decrease with age, so that older children may be asymptomatic (Burgess et al., 1964) and are able to tolerate sugars in the amount normally taken in the diet.

Lactose intolerance resulting from lactase deficiency is being increasingly recognized in adults (Dunphy et al., 1964; Haemmerli et al., 1965 ; McMichael et al., 1965), and is probably not uncommon. Sucrose intolerance due to an absent sucrase activity in the jejunal mucosa, and first manifesting in adult life, has not been previously described; such a case, in which the mucosal disaccharidases have been quantitatively assayed, is now reported.

\section{Case Report}

The patient, a motor mechanic, was aged 27 in March 1963, when he became unwell with pyrexia, headache, and abdominal pain during an epidemic of gastro-enteritis. Two days later he developed vomiting and diarrhoea, which slowly improved over the next week. A month later the diarrhoea recurred without systemic disturbance and persisted. He passed from 4 to 10 large, soft, sour-smelling stools a day. His general health remained good and he did not lose weight. He had had no serious illnesses previously. His mother remembered that he was difficult to wean because he disliked baby foods, and he was therefore partially breast-fed until the age of 15 months. He then ate sugar and starch-containing foods freely, though wartime rationing limited his sucrose intake after the age of 3. He always had a tendency to constipation and there were no episodes of diarrhoea.

In May 1963 he was admitted to St. George's Hospital, Tooting, for investigation, but no cause for his symptoms could be found. Routine blood and biochemical examinations performed on many occasions gave normal results. No pathogenic organisms were detected on stool culture. Barium examination of the gut and biopsy of the small intestine showed no abnormality. Pancreatic function tests and urinary 5-hydroxyindole-acetic acid excretion were normal. The symptoms were unaffected by a gluten-free diet, but a lactose-free diet led to short-lived improvement. Laparotomy was performed because of the persistence of distressing symptoms, but no macroscopic abnormality was discovered.

In December 1964 he was transferred to Hammersmith Hospital for further metabolic studies. The faecal fat was 4 g./day and nitrogen $3 \mathrm{~g} . /$ day on a diet containing $70 \mathrm{~g}$. of fat and $70 \mathrm{~g}$. of protein a day. The stools were noticed to be sour-smelling and acid, with a $p \mathrm{H}$ of 5 . A provisional diagnosis of disaccharide intolerance was confirmed by the failure of blood glucose to rise and an increased diarrhoea after sucrose ingestion and by enzyme

* Medical Registrar, Postgraduate Medical School of London.

† Medical Registrar, St. George's Hospital, Tooting Grove, London. f Consultant Pathologist, Queen Elizabeth Hospital for Children, London. studies of the jejunal mucosa. He was discharged from hospital a week after starting a sucrose-free and restricted starch diet and has since remained well.

\section{Methods}

Initially the patient was on a normal ward diet estimated to contain 50-80 g. of sucrose a day. After 10 days sucrose was eliminated from the diet, and after a further three days starch intake was restricted to $150 \mathrm{~g}$. a day. Carbohydrate tolerance was determined after an overnight fast by estimating blood glucose levels, using a specific glucose oxidase method, after ingestion of $50 \mathrm{~g}$. of the test carbohydrate in water.

The acidity of the stools was estimated with moistened $p H$ papers. The lactic-acid content of pooled specimens of stools was determined by the method of Barker and Summerson (1941). Urinary sugars were demonstrated by paper chromatography, and 24-hour indican excretions were measured by the method of Curzon and Walsh (1962). Stools were examined for sugars by direct paper chromatography of the fluid stool, butanolacetic acid-water or isopropyl alcohol-water being used as solvent systems. Jejunal mucosal biopsies were obtained by means of a Crosby capsule (Crosby and Kugler, 1957), and specimens were examined by dissecting, light, and electron microscopes. Lactase, maltase, palatinase, and sucrase activities in the jejunal mucosa were measured as described by Burgess et al. (1964). Palatinose was used as substrate instead of isomaltose, since it is also hydrolysed by isomaltase. The histochemical studies were performed by the methods described by Pearse (1959) and Barka and Anderson (1963).

\section{Results}

\section{Carbohydrate-tolerance Tests}

Blood-glucose levels after ingestion of glucose, lactose, maltose, and a glucose-fructose mixture were remarkably similar, with a maximum rise of between 70 and $90 \mathrm{mg} . / 100 \mathrm{ml}$. at 30 minutes (Fig. 1). There was little change in the bloodglucose level after sucrose, and the patient suffered from abdominal distension and marked diarrhoea, in contrast to the other carbohydrates, ingestion of which led to no exacerbation of the symptoms. The starch test gave a blood-glucose curve intermediate between that for sucrose and other tolerance tests and also caused an exacerbation of the patient's symptoms. No carbohydrates were demonstrated in the urine after the glucose, maltose, lactose, and starch tolerance tests, but approximately $2 \mathrm{~g}$. of sucrose appeared in a six-hour urine collection made after the test dose of sucrose.

\section{Urinary Indican}

Urinary indican excretion was very low while the patient wás on a normal diet, only once exceeding $20 \mathrm{mg}$./day. After starting the sucrose-free and starch-restricted diet the levels rose to between 20 and $46 \mathrm{mg}$./day, compared with a normal range of $28-68 \mathrm{mg}$./day. 


\section{Stools}

On a ward diet the patient's stools weighed on an average $580 \mathrm{~g}$./day. This increased to $860 \mathrm{~g}$. after the sucrose test and to $800 \mathrm{~g}$. after starch (Fig. 2). The stools were persistently acid, the lowest $p H$ of 4.5 being recorded after the sucrose tests, at which time a large amount of sucrose was present also. On the ordinary ward diet, before elimination of sucrose, the lactic acid content of a 24-hour stool collection was $4.4 \mathrm{~g}$., estimated on only one occasion. Stool culture of the same specimen yielded an almost pure growth of lactobacilli able to ferment lactose, maltose, and sucrose.

On the restricted starch diet the patient's stools averaged $250 \mathrm{~g}$./day, with a $\mathrm{pH}$ of 7 and a lactic acid content of less than $250 \mathrm{mg}$. Stool culture now gave a profuse mixed growth of Escherichia coli and Streptococcus faecalis together with some lactobacilli.

\section{Enzyme Levels in Jejunal Mucosa}

The biopsy specimen of mucosa appeared normal under both dissecting and light microscopes. Electron microscopy also

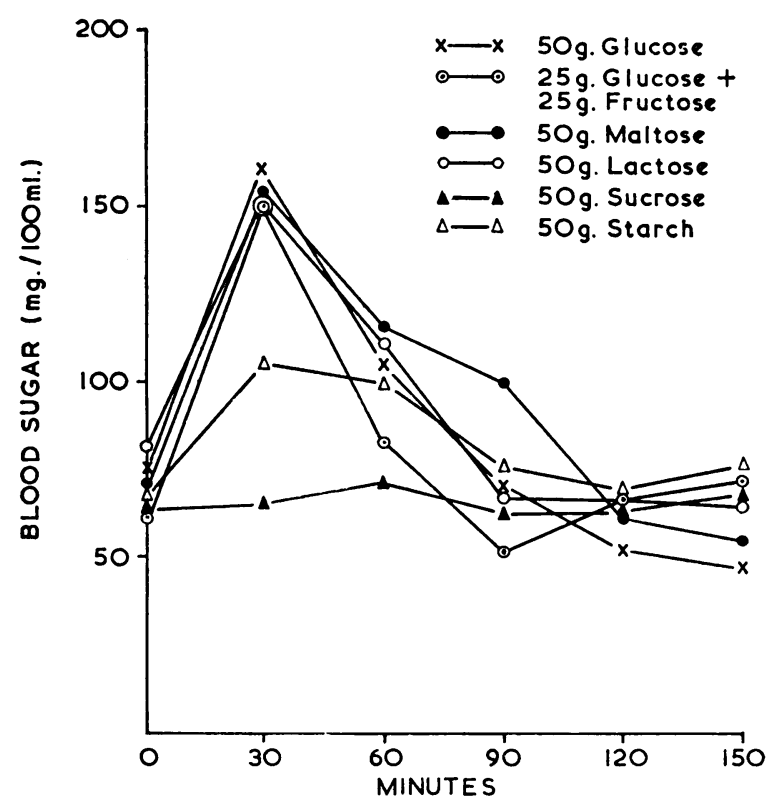

Fig. 1.-Changes in blood-glucose levels after ingestion of $50 \mathrm{~g}$. carbohydrate.

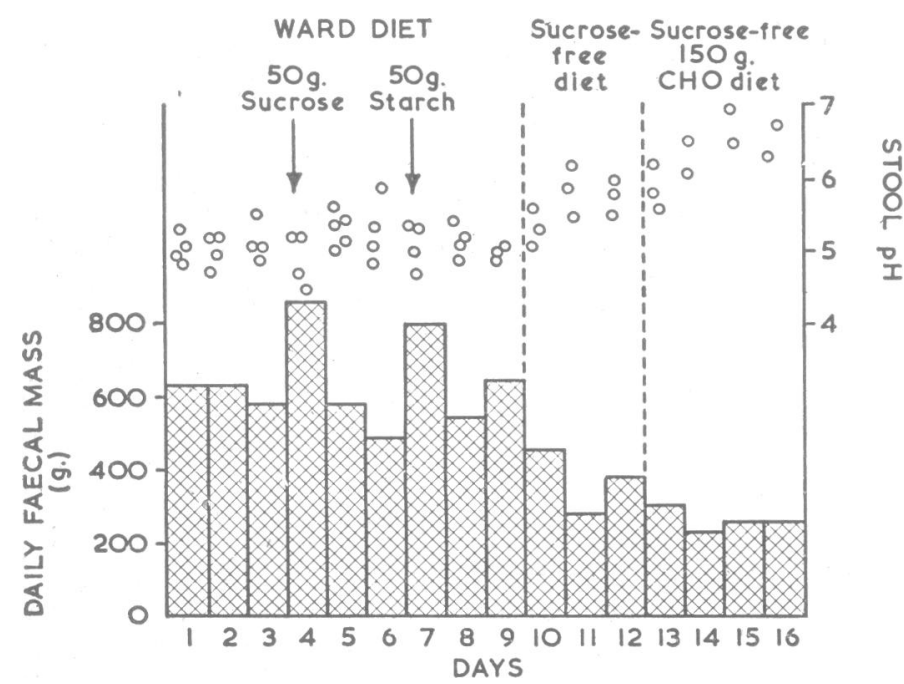

FTG. 2.-Changes in weight and $\mathrm{pH}$ of stools with patient on normal diet, after carbohydrate loading tests, and after sucrose-free and starchrestricted diet. showed no abnormality, and in particular the brush border of the epithelial cells was apparently intact. Histochemical studies showed normal staining reactions for non-specific alkaline phosphatase, acid phosphatase, non-specific esterase, E-600 resistant esterase, $\beta$-glucuronidase, leucine-aminopeptidase, mono-amino-oxidase, succino-dehydrogenase, glucose-6-phosphatase, N.A.D.H. (nicotinamide-adenine dinucleotide)diaphorase, N.A.D.P.H. (nicotinamide-adenine dinucleotide phosphate)-diaphorase. On the other hand, the staining reaction for $\alpha$-glucosidase was markedly reduced.

The results of the disaccharidase assays on biopsies taken on two separate occasions are given in Table I, with, for comparison, normal levels in children obtained by one of us (Burgess et al., 1964), which are very similar to those found in normal adults. In both specimens sucrase activity was virtually absent, the palatinase activity was very low, while the maltase activity was markedly reduced. The lactase activity in the second biopsy was within the normal range, though the first specimen showed a somewhat reduced level. This was probably a consequence of the persistent diarrhoea.

\begin{tabular}{|c|c|c|c|c|c|}
\hline \multirow{2}{*}{\multicolumn{2}{|c|}{ Enzyme }} & \multicolumn{2}{|c|}{ Patient } & \multicolumn{2}{|c|}{ Normal Children } \\
\hline & & Specimen 1 & Specimen 2 & Range & Mean \\
\hline $\begin{array}{l}\text { Lactase } \\
\text { Maltase } \\
\text { Palatinase } \\
\text { Sucrase }\end{array}$ & $\begin{array}{l}\ldots \\
\cdots \\
\cdots\end{array}$ & $\begin{array}{l}1 \cdot 1 \\
0 \cdot 7 \\
0 \cdot 15 \\
0\end{array}$ & $\begin{array}{l}3.0 \\
3.5 \\
0.2 \\
0.1\end{array}$ & $\begin{array}{l}2 \cdot 65-5 \cdot 0 \\
17 \cdot 6-35 \cdot 6 \\
2 \cdot 6-2 \cdot 8 \\
5 \cdot 0-8 \cdot 1\end{array}$ & $\begin{array}{r}3 \cdot 5 \\
25 \cdot 0 \\
2 \cdot 7 \\
7 \cdot 0\end{array}$ \\
\hline
\end{tabular}

To ascertain whether an inhibitor was responsible for the absent sucrase activity the glucose produced by a homogenate containing equal weights of jejunal mucosa from the patient and a control subject was determined after incubation with the appropriate disaccharide for 20 minutes. The results are shown in Table II, together with the levels of enzyme activity of each individual biopsy. It will be noted that the activities of the mixture are almost identical with those predicted from the activities of each component. It is also interesting to note the chance finding of an absent lactase activity in the "normal" control. Investigation of this subject demonstrated a severe lactose intolerance.

Table II.-Effect on Disaccharidase Activities of Addition of Mucosal Homogenate from a Control to that of Patient

\begin{tabular}{|c|c|c|c|c|c|c|c|}
\hline \multicolumn{3}{|c|}{$\begin{array}{l}\text { Enzyme Levels } \\
\text { (Units) }\end{array}$} & \multicolumn{5}{|c|}{$\begin{array}{l}\text { Glucose Formed in Mucosal Homogenate } \\
\text { (mg.) }\end{array}$} \\
\hline & \multirow{2}{*}{ Patient } & \multirow{2}{*}{ Control } & \multirow{2}{*}{ Substrate } & \multirow{2}{*}{ Patient } & \multirow{2}{*}{ Control } & \multicolumn{2}{|c|}{$\begin{array}{l}\text { Patient + Control } \\
\text { (Equal Amounts) }\end{array}$} \\
\hline & & & & & & Found & $\begin{array}{l}\text { Calcu- } \\
\text { lated }\end{array}$ \\
\hline $\begin{array}{l}\text { Lactase .. } \\
\text { Maltase .. } \\
\text { Palatinase } \\
\text { Sucrase .. }\end{array}$ & $\begin{array}{l}3 \cdot 0 \\
3.5 \\
0 \cdot 2 \\
0.1\end{array}$ & $\begin{array}{r}0.1 \\
12.5 \\
1.2 \\
4.4\end{array}$ & $\begin{array}{l}\text { Lactose } \\
\text { Maltose } \\
\text { Palatinose } \\
\text { Sucrose }\end{array}$ & $\begin{array}{l}0 \cdot 4 \\
9 \cdot 7 \\
4 \cdot 6 \\
7 \cdot 9\end{array}$ & $\begin{array}{r}12.0 \\
2.7 \\
0.7 \\
0.4\end{array}$ & $\begin{array}{l}6 \cdot 4 \\
6 \cdot 4 \\
2 \cdot 7 \\
4 \cdot 0\end{array}$ & $\begin{array}{l}6 \cdot 2 \\
6 \cdot 2 \\
2 \cdot 7 \\
4 \cdot 2\end{array}$ \\
\hline
\end{tabular}

\section{Discussion}

The enzymes mediating the hydrolysis of dietary disaccharides are now known to be located in the intestinal mucosa. Eight such enzymes have been characterized and some have been shown to have overlapping specificities (Dahlqvist, 1962, 1963 ; Auricchio et al., 1963c). Disaccharide intolerance may result not only from a congenital absence of sucrase or lactase, but may also be acquired, and this may be of more frequent occurrence than the inherited form. It is likely to occur whenever the mucosal epithelium of the small bowel is damaged, and has been described after gastro-enteritis (Sunshine and Kretchmer, 1964), in coeliac disease and other malabsorptive states (Cooke et al., 1963 ; Plotkin and Isselbacher, 1964 ; Levin et al., 1965), 
cystic fibrosis (Cozzetto, 1963), giardiasis (Durand et al., 1963), and severe malnutrition (Cevini et al., 1962).

In the present case carbohydrate-loading tests demonstrated a complete intolerance to sucrose and some intolerance to starch. Measurement of enzyme activities of the jejunal mucosa on two occasions showed that the sucrose intolerance was due to the virtual absence of sucrase. The reduced tolerance to starch could be correlated with the finding of reduced maltase and isomaltase (palatinase) activities. Starch is hydrolysed, chiefly by pancreatic amylase, in the lumen of the intestine, mainly to maltose and to a small extent, about $4 \%$, to isomaltose. Dahlqvist (1962) has shown that at least $25 \%$ of the maltase activity is attributable to sucrase, and Auricchio et al. (1963c) have claimed that sucrase and isomaltase (palatinase) enzymes together account for about $80 \%$ of the total maltase activity of the intestinal mucosa in the human. The virtual absence of sucrase in the present subject and the markedly reduced palatinase activity are together sufficient to account for the reduced maltase activity found, and therefore for the impaired tolerance to starch.

This association of starch and sucrose intolerance has been noted by others (Auricchio et al., 1962, 1963a ; Anderson et al., 1962,1963 ) and seems to be a frequent feature of hereditary sucrose intolerance. The finding of a very low isomaltase activity with absent sucrase activity, as in our case, has also been previously observed (Auricchio et al., 1963a; Burgess et al., 1964), and Auricchio et al. (1963c) have suggested that a common mechanism regulates the levels of both enzyme activities.

The large load of unsplit disaccharides reaching the colon explains the acid diarrhoea. The growth of $E$. coli is inhibited in an acid medium, resulting in a lowered indole production and therefore the reduced urinary indican excretion found in the present case. Rapid recolonization of the bowel with $E$. coli and Str. faecalis occurred after the patient started the restricted diet.

The most interesting feature of this patient's disease is its apparent onset in adult life. The symptoms of patients with hereditary sucrose intolerance tend to improve with age (Burgess et al., 1964) and proved sucrose intolerance in adults is exceptionally rare. Only three cases have been previously described (Iversen, 1942 ; Jensen, 1963 ; Sonntag et al., 1964), and all three patients had had diarrhoea from childhood. Our patient had no such history in early life, but the unusually prolonged period of breast-feeding together with wartime sugar rationing may have masked a congenital sucrase deficiency. The normal anatomical appearance of the small-intestinal mucosa and the normal levels of 11 other enzymes demonstrated histochemically are consistent with this interpretation. In addition, the pattern of disaccharidase activities-that is, virtually absent sucrose, very low palatinase, reduced maltase, and relatively normal lactase levels-is very similar to that found in children with hereditary sucrose intolerance (Burgess et al., 1964).

There is the alternative possibility of an acquired sucrose intolerance. Most of the causes of this condition were excluded in our patient, but it is not possible to prove that the disaccharide intolerance was not acquired as a result of an attack of gastro-enteritis. The absence of family history and the acute onset of the illness are in favour of this view. If this were the case, however, it could be expected that intolerance to lactose rather than to sucrose would have resulted. Thus temporary lactose intolerance has been described during bacterial and non-bacterial diarrhoeal disease (Cevini, 1962 ; Sunshine and Kretchmer, 1964). Again, in gluten-induced enteropathy the enzyme activity first and most severely affected is lactase (Levin et al., 1965), not sucrase. Lactose intolerance was never demonstrated in our patient, and the apparent clinical response to a lactose-free diet was probably due to a simultaneous reduction in sucrose intake, as the patient stopped his habit of drinking large quantities of sweetened milky tea.
Finally, no mucosal inhibitors of disaccharidase activities, such as might result in an acquired disaccharide intolerance, could be demonstrated.

It seems most likely, therefore, that this patient has a genetically determined condition which has been unmasked by an episode of acute damage to the intestinal mucosa. Probably some of the cases of lactose intolerance first manifesting in adult life reported by Dunphy et al. (1964), Haemmerli et al. (1965), and McMichael et al. (1965) are similarly due to inherited enzyme deficiency. Confirmation of this view must await the report of family studies in cases where siblings are involved.

\section{Summary}

The onset in adult life of intolerance to sucrose and an impaired starch tolerance, coincident with an acute diarrhoeal episode, is described in a 29-year-old man with a two-year history of diarrhoea. Enzyme assays of jejunal mucosa showed a virtual absence of sucrase, with very low palatınase and reduced maltase activities, and it is suggested that this is a case of hereditary sucrose intolerance, unmasked by an acute attack of gastro-enteritis. Response to a sucrose-free and restricted starch diet has been satisfactory.

We are grateful to Dr. J. Dow, St. George's Hospital, Tooting, and Dr. C. C. Booth, Hammersmith Hospital, for permission to publish this case. We wish to thank Dr. E. Ann Burgess for the mucosal enzyme studies; Dr. E. O. Riecken and Professor A. G. B. Pearse for the histochemical studies; Mr. J. Spencer for urine chromatography; Dr. W. Payne for the faecal lactic acid determinations ; and the Staff of the Metabolic Unit, Hammersmith Hospital, for making this study possible. One of us (G.N.) is indebted to Smith Klein and French Ltd. for a grant.

\section{REFERENCES}

Anderson, C. M., Messer, M., Townley, R. R. W., and Freeman, M. (1963). Pediatrics, 31, 1003

Auricc and Robinson, M. J. (1962). Lancet, 2, 556. icchio, S., Dahlqvist, A., Mürest, G., and Prader, A. (1962). Ibid., 1, 1303.

Rubino, A., Landolt, M., Semenza, G., and Prader, A. (1963b). Lancet, $2,324$.

- Tozi, R., Semenza, G., Landolt, M., Kistler, H., and Prader, (Basel), 3,193

and "Biblisterson, P. J. (1963). Histochemistry, Theory, Practice, and Bibliography. Harper, New York.

Barker, S. B., and Summerson, W. H. (1941). F. biol. Chem., 138, 535. rgess, E. A., Levin, B., Mahalanabis, D., and Tonge, R.' E. (1964). Arch. Dis. Childh., 39, 431.

831. G., Giovannini, M., and Careddu, P. (1962). Minerva pediat., 14,

(1963). G. Fone, D. J., Cox, E. V., Meynell, M. J., and Gaddie, R. (1963). Gut, 4, 279.

Cozzetto, F. J. (1963). Pediatrics, 32, 228

Crosby, W. H., and Kugler, H. W. (1957). Amer. 7. dig. Dis., 2, 236

Curzon, G., and Walsh, J. (1962). Clin. chim. Acta., 7, 657.

Dahlqvist, A. (1962). F. clin. Invest., 41, 463 .

(1963). Symposium of the 2nd World Congress on Gastroenterology in Munich edited by $\mathrm{H}$. Schon. Karger, Basel.

Hammond, J. B., Crane, R. K., Dunphy, J. V., and Littman, A (1963). Gastroenterology, 45, 488. Dunphy, J. V., Littman, A., Hammond, J. B., Forstner, G., Dahlqvist,

Durand, P. (1958). Minerva pediat., 10, 706 .

Lamedica, G. M., and Vatterino, G. (1963). G. Mal. infett., 15, 564. G., Auricchio, Kistler, H., Ammann, R., Marthaler, T., Semenza versen, P. (1942). Nord. Med., 16, 2860 . (1965)

Jensen, P. E. (1963). Acta paediat. (Uppsala), 52, Suppl. No. 140, p. 119.

published, E. A., Young, W. F., and Pringle, E. M. (1965). To be published.

McMichael, H. B., Webb, J.. and Dawson, A. M. (1965). Lancet, 1, 717

Pearse, A. G. E. (1959). Histochemistry, Theoretical and Applied. 2nd ed. Churchill, London.

1033. R., and Isselbacher, K. J. (1964). New Engl. 7. Med., 271,

Sonntag, W. M., Brill, M. L., Troyer, W. G., jun., Welsh, J. D., Semenza, G., and Prader, A. (1964), Gastroenterology, 47, 18 .

Sunshine, P., and Kretchmer, N. (1964). Pediatrics, 34, 38.

Wei ers, H. A., van de Kamer, J. H., Mossel, D. A. A., and Dicke, 